NIHON REOROJĪ GAKKAISHI Vol.26, No.3, 143 150 (1998)

CC1998 The Society of Rheology, Japan

\title{
An Automatic Simulation System of Film Blowing Processing
}

\author{
Tatsuya SHOJI", Shigeru YAO", and Eiichi KAMEI \\ Polymer Laboratory, Ube Industries Ltd. \\ Minamikaigan8-1,Ichihara,Chiba 290,Japan
}

\begin{abstract}
An automatic simulation system of film blowing processing was constructed. Band Matrix method was chosen to solve some differential equations. Newton-Raphson method was combined with it to search for the most suitable molding conditions automatically. Newtonian fluid was assumed for the polymer melt. The validity of this system was demonstrated by comparison of simulated results to experimental data.
\end{abstract}

Key Words : Blowing film processing / Simulation system / Band Matrix method /

Newton-Raphson method / Newtonian fluid /

\section{インフレーション成形の自動シミュレーションシステム}

庄司 達也*、八尾 滋、、亀井 衛一*

（原稿受理：1997 年11月 12 日）

\section{1. 诺}

インフレーション成形は、高分子フィルムの作製法ては、T タイと並んで最も一般的な手法である。この成形は、榯脂の種 類、吐出量、温度、バプル内压、引き取り速度及び冷却風量・ 温度なと数多くの因子が複雑に絡み合って、成形されるフィル 么の幅、厚み、配向及び強度などの物性に影響を及ほしている. インフレーション成形に関する初期の理論的な考察は、1970 年にPearson と Petrie ${ }^{1) 2}$ が行っている. その後、等温モテルを 用いた解析を Han と Park ら ${ }^{3)}$ か、樹脂の結晶化熱を考虑した 解析を Kanai と White ら ${ }^{4) か 、 、 ま た ~ M i n o s h i m a ~ ら ~}{ }^{5)}$ はバブルの 安定性については解析を行っている. 近年てはつロストライン 近傍での枇脂を結晶部と溶融部の二相領域で考えてより詳細 な解析を Campbell ら 6)が武みている. さらに樹脂の粘弾性的 性質を構成方程式を用いて表わす試みもなされており、 Maxwell モテルては Cain ら ${ }^{7 か 、 L e o n o v ~ モ テ ゙ ル て ゙ は ~ T a n n e r ~ ら ~}{ }^{8)}$ などが行っている. Papanastasiou ら ${ }^{9}$ は樹脂の举動を成形タイ スの中から考虑に入れた PSM 皘分型構成方程式をもとにシミ

\footnotetext{
*宇部興産株式会社研究開発本部高分子研究所

于290-0045 千葉県市原市五井南海岸 8-1
}

ュレーションを行っている. Liu ら ${ }^{10)}$ は、内展によるバブル半 径の減少について考察している.

このようなシミュレーションを行う際には、計算手法を確立 させることは最も重要なことである. 通常、微分方程式の解法 としてよく用いられるものに Runge-Kutta 法がある.この手法 は、変数を与えてやれば比教的簡便に微分方程式を解くことが 出来ろが、インフレーション成形シミュレーションのように、 変数を探索しながら解く場合には解の発散を起こすことがあ り、目的とする解を求めることは難しい，一方、Runge-Kutta 法と比へろと計算時間がかかるが解の収束性の良い方法とし て Band Matrix 法 ${ }^{11)}$ がある. しかしこの手法のみでは、内压や 引き取り张力などに適当な変数を入力して、これに合致するフ イルム形状を導き出すため、本来のインフレーション成形シミ ュレーションに求められろ、成形したいフィルム形状を達成す ろための成形条件の導出に適用することは不可能である. そこ で今回我々は、複数の変数から最適解を探し出す方法として、 一次方程式の解法である Newton-Raphson 法を利用し、Band Matrix 法と組み合わせて、䙡数の変数の最道解を探索し要求さ れろ成形結果を自動的に導き出すインフレーション成形自動 シミュレーションシステムを構築した. また、この計算結果を 
各実験結果と比䡈し、本システムて非常に簡単に有効な結果を 得ることが出来たのて報告する。

\section{2. 理}

Fig.1はインフレーション成形部の模式図である. 榯脂の流

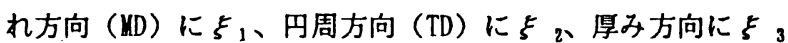
の直交座標を設定する，溶融榀脂がタイスを出てフロストライ ンにて冷却固化するまてのバブル上の任意の点て、MDには式 (1)て表す力のつりあいが成立する.

$$
2 \pi R \cos \theta H \sigma_{11}+\pi\left(R_{f}^{2}-R^{2}\right) \Delta P=F z
$$

ここてRはバブル半径、Hはフィルムの厚み、 $\sigma_{\mathrm{ii}}$ は $\xi_{\mathrm{i}}$ 方向 の応力、 $R_{f}$ は最終バブル半径、 $\Delta P$ は内压、 $F z$ は $z$ 軸方向の 張力でる.

一方、応力 $\sigma_{11} 、 \sigma_{22}$ 之内压 $\Delta P$ との間には式(2) (4)が成 立する。

$$
\begin{aligned}
& \Delta P=H\left[\frac{\sigma_{11}}{R_{L}}+\frac{\sigma_{22}}{R_{H}}\right] \\
& R_{L}=-\frac{\sec ^{3} \theta}{R^{\prime \prime}} \\
& R_{H}=R \sec \theta
\end{aligned}
$$

だだしこここで薄膜を仮定し、フィルムの自重の影既や表面 㖘力は無視した.

また、フィルムの熱エネルギーの放出は、バブルの表面にお いて冷却風による強制対流之放射のみにより行なわれると仮 定する. その際、㯕脂が結晶化を伴うならばフロストラインて の結晶化発熱の影響を考えるへきでるが、今回はその効果も 無視している. この場合フィルム表面ての熱の収支は式(5)て 表されろ.

$$
\begin{aligned}
\rho C_{p} R H V_{1} T^{\prime}= & -R \sqrt{1+R^{2}}\left(T-T_{\text {air }}\right) h c \\
& -R \sqrt{1+R^{2}{ }_{m}} \sigma_{S B}\left(T^{4}-T_{\text {room }}^{4}\right)
\end{aligned}
$$

ここて、、 $\rho$ は密度、Cp は比熱、 $T$ は温度、 $T_{a i r}$ は冷却風温度、 $h c$ は熱伝達係数、 $\varepsilon_{m}$ は㬏射率、 $\sigma_{s s}$ はステファンーボルツ マン定数、 $T_{\text {rom }}$ は梁囲気温度でる.

冷却風によろ強制対流はバブル形状や位置によって異なり、 それに伴い熱伝達係数は变化するため、計算てはエアリングの 吹き出しロからの距離に応して熱伝達係数を変化させた.

榯脂の粘弹性的な性質を Newton 流体て仮定すると、各方向 の応力は式(6)て表すことがてきる.

$$
\sigma=-p 1+2 \eta e
$$

ここて、のは応力テンソル、 $p$ は等方性圧力項、1は単位テン ソル、eは歪み速度テンソル、クは钻度である。

バブル表面はバブルの厚み方向て大気圧とカのつりあいが
取れているので $\sigma_{33}=0$ であり、流れ方向の応力 $\sigma_{11}$ おび半 径方向の応力 $\sigma_{22}$ は、各々、式(7)及び(8)で表わされる.

$$
\begin{aligned}
& \sigma_{11}=-p+2 \eta e_{11}=2 \eta\left(e_{11}-e_{33}\right) \\
& \sigma_{22}=-p+2 \eta e_{22}=2 \eta\left(e_{22}-e_{33}\right)
\end{aligned}
$$

よって、各方向の応力は粘度の関数て表わすことがてきる．ま た、粘度の温度依存性がアレニウス式に従うとすると式(9)及 び(10)で示すことができる.

$$
\begin{aligned}
& \eta=A_{E} \exp \left[\frac{E}{R T}\right] \\
& A_{E}=\eta_{0} \exp \left[\frac{-E}{R T}\right]
\end{aligned}
$$

ここでEは流動の活性化エネルギー、Rは気体定数、ク。は温 度 $T_{0}$ におけるぜ口韵断粘度である。

一方、椹脂の挙動を正確に粘弾性体として稃価すると、これ らの式は Newton 流体の時と比へて襘雑化してくろ. 各位置に おいて、楜脂はひずみ速度 $e_{11}$ おひひ $e_{22}$ の異なる非等二軸伸長 応力を受け变形していく．またひずみ速度や時間、温度によっ ては strain-harden 現象による応力の非線形性む考えられ、考虑 は難しい，粘弾性体の構成方程式に Leonov モテルを選択した 場合、各方向の応力は次の連立微分方程式を解くことによって 得られる.

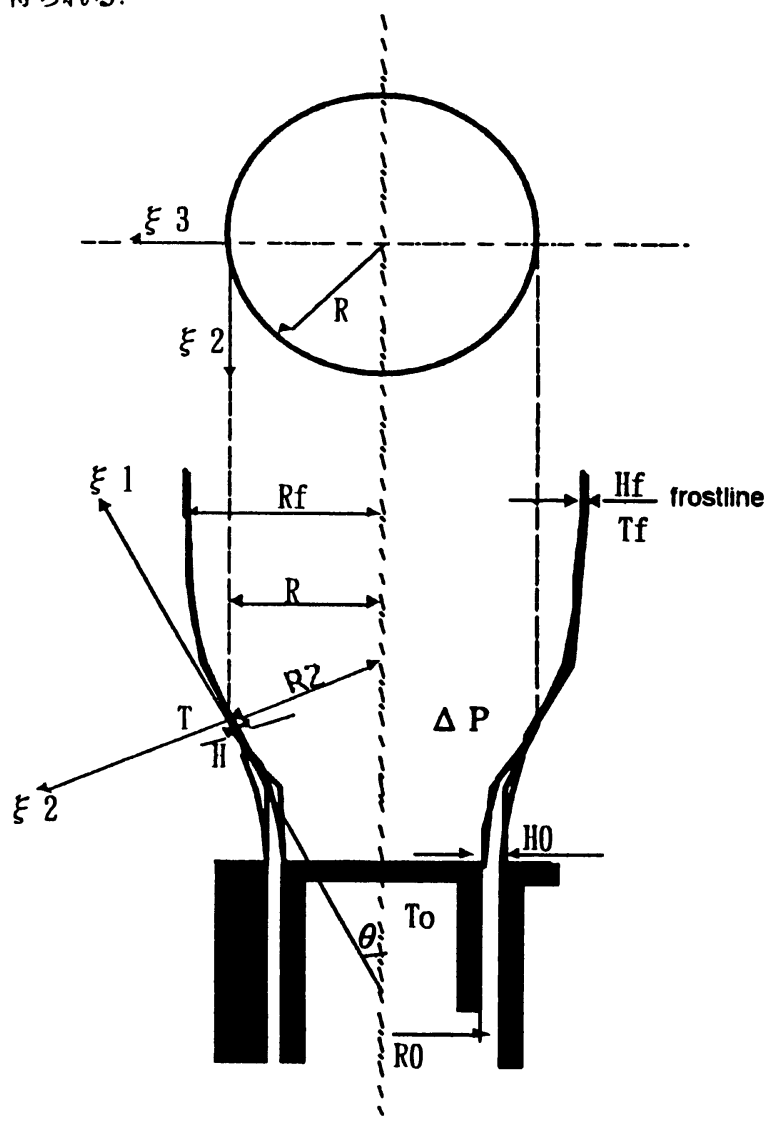

Fig.1 Schematic model of film blowing processing 


$$
\begin{gathered}
\sigma_{11}=\sum G n\left(\lambda n_{11}^{2}-\lambda n_{11}^{-2} \lambda n_{22}^{-2}\right) \\
\sigma_{22}=\sum G n\left(\lambda n_{22}^{2}-\lambda n_{11}^{-2} \lambda n_{22}^{-2}\right) \\
\frac{d \lambda n_{11}}{d t}-e_{11} \lambda n_{11}+ \\
\frac{\lambda n_{11}\left[2\left(\lambda n_{11}^{2}-\lambda n_{11}^{-2}\right)-\left(\lambda n_{22}^{2}-\lambda n_{22}^{-2}\right)+\lambda n_{11}^{2} \lambda n_{22}^{2}+\lambda n_{11}^{-2} \lambda n_{22}^{-2}\right]}{12 m \exp [\beta F(\lambda n)]}=0 \\
\frac{d \lambda n_{22}}{d t}-e_{22} \lambda n_{22}+ \\
\frac{\lambda n_{22}\left[2\left(\lambda n_{22}^{2}-\lambda n_{22}^{-2}\right)-\left(\lambda n_{11}^{2}-\lambda n_{11}^{-2}\right)+\lambda n_{11}^{2} \lambda n_{22}^{2}+\lambda n_{11}^{-2} \lambda n_{22}^{-2}\right]}{12 \pi n \exp [\beta F(\lambda n)]}=0
\end{gathered}
$$

$F(\lambda n)=\frac{\left(\lambda n_{11}^{2}+\lambda n_{22}^{2}+\lambda n_{11}^{-2}+\lambda n_{22}^{-2}+\lambda n_{11}^{2} \lambda n_{22}^{2}+\lambda n_{11}^{-2} \lambda n_{22}^{-2}-6\right)}{2}$

ここて、 $e_{\mathrm{ii}}$ は各方向のひずみ速度、 $\lambda_{\mathrm{ii}}$ は各方向の伸長比、 $n$ は次数、 $G_{\mathrm{n}}$ は $\mathrm{n}$ 次の悢和弹性率、 $\tau_{n}$ は $\mathrm{n}$ 次の悢和時間、 $\beta$ は strain-harden パラメーターて、簡単のため $\beta=0$ とした. また、 第 2 ニュートン粘度パラメーターは 0 としてある.

境界条件は成形ダイス出ロとフロストラインに置いて以下 の条件を用いた。ここで、 $T_{B}$ は $F z や \triangle P て ゙$ 决まる定数である。 1) 成形ダイス出口て

$$
\begin{aligned}
& R=R_{0} \\
& H=H_{0} \\
& T=T_{0} \\
& T_{B}^{\prime}=0
\end{aligned}
$$

2 ) フロストラインにおいて

$$
\begin{gathered}
R^{\prime}=0 \\
H^{\prime}=0 \\
T^{\prime}=0 \\
T_{B}=\frac{F z}{2 \pi \eta_{0} H_{0} V_{0}}-\frac{R_{0}^{2} \Delta P}{2 \eta_{0} H_{0} V_{0}} \cdot \frac{R_{f}^{2}}{R_{0}^{2}}
\end{gathered}
$$

\section{3. 尌算手法}

成形タイス出ロからフロストラインまての距雍を $\mathrm{m}$ 等分 $(\mathrm{m}$ ミ100）に細分化した各点において、これら連立微分方程式を 連続的に解くことでバブル形状や温度特性を求めることが出 来ろ。今回我々は微分方程式の解法として、Runge-Kutta 法よ

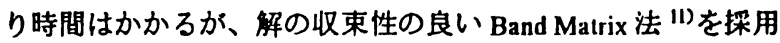
した.

入力条件は、成形機条件、榯脂条件、成形条件に分かれる.

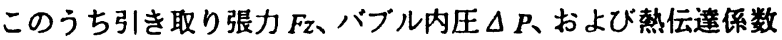
$U_{0}$ は通常成形時には測定されないために変数であり、これら によって計算結果は大きく異なる.よって目的の計算結果を得
ろためにはこれら 3つの変数の最適解を探索する必要がある. そこでFig. 2 のようなインフレーション成形自動シミュレ ーションシステムを構築した. 初期条件を入力し、Band 法て 連立微分方程式を解き、各位圈に於けろバブル半径 $R$ 、温度 $T$ 、 厚み $\boldsymbol{H}$ などを求める. また、成形後のフィルム形状として厚 み $H$ 、成形条件としてブロー比 $R_{f} / R_{0}$ 、および榯脂テータとし て結晶化温度 $T_{f}$ と計算てのフロストラインにおける計算解を 比䖝し、Newton-Raphson 法と Gauss-Jordan 法を組み合わせて上 記の 3 つの梁数を变化させ最適解を発見するまで計算を行う アルゴリズムに基づいてプログラムを作成した. また、熱伝達 係数はエアリング吹き出しロでバブル位圈の値を最大にし て、離れるに従い指数関数的に隇少させた. すへてての式、条件 值および変数の次元数は、無次元化して解いた.

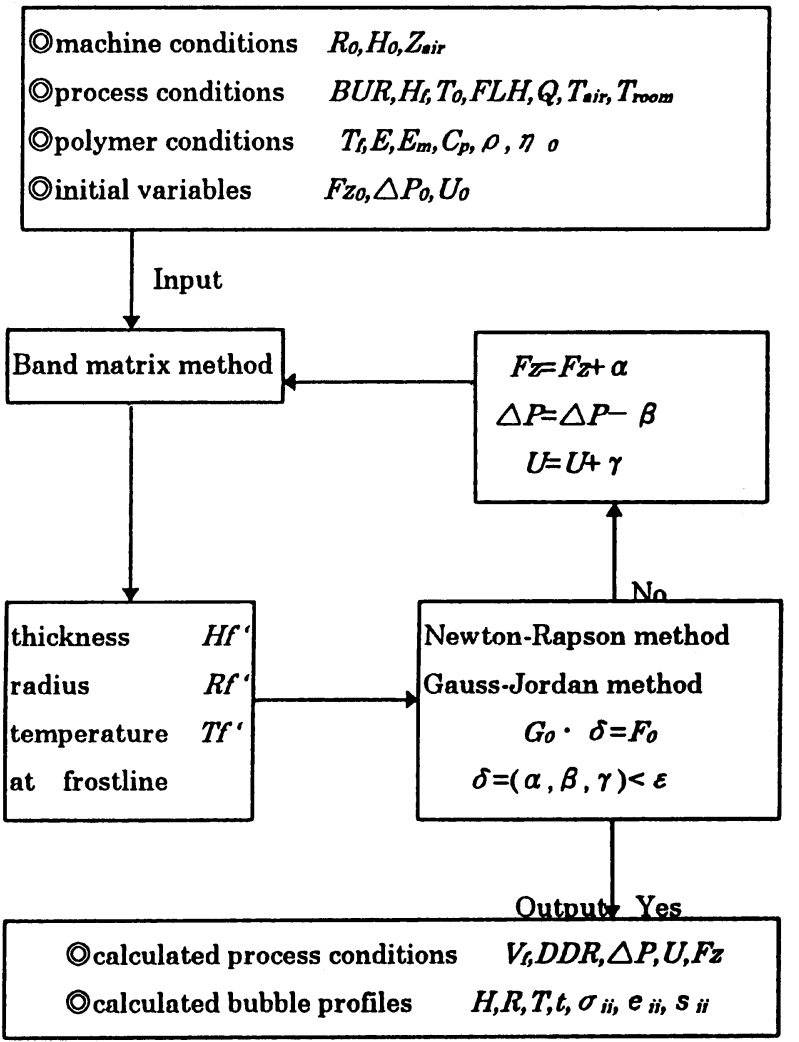

Fig.2 Automatic simulation system of film blowing processing

Table I Processing conditions of film blowing

\begin{tabular}{ccccccccccc}
\hline & $\begin{array}{c}R o \\
\mathrm{Cm}\end{array}$ & $\begin{array}{c}H o \\
\mathrm{~mm}\end{array}$ & $\begin{array}{c}{ }^{\circ} \mathrm{C} \\
\mathrm{g} / \mathrm{s}\end{array}$ & $\begin{array}{c}\boldsymbol{Q} \\
\mathrm{Pas}\end{array}$ & $\begin{array}{c}\text { FLH } \\
\mathrm{Cm}\end{array}$ & BUR & $\begin{array}{c}H f \\
\mu \mathrm{m}\end{array}$ & $\begin{array}{c}T f \\
{ }^{C} \mathrm{C}\end{array}$ \\
\hline \hline $\begin{array}{c}\text { Farber } \\
\text { case3 }\end{array}$ & 3.175 & 1.27 & 185 & 3.07 & 12340 & 39.2 & 2.94 & 86.4 & 100 \\
$\mathrm{~A}$ & 3.75 & 1.00 & 190 & 2.39 & 15000 & 37.0 & 2.33 & 40.0 & 110 \\
B & 7.5 & 2.00 & 200 & 3.92 & 22300 & 40.0 & 1.22 & 42.8 & - \\
C & 7.5 & 2.50 & 195 & - & 10020 & - & - & - & - \\
\hline
\end{tabular}




\section{4. 成形実医}

インフレーション成形実験は 3 種類の成形機 $(\mathrm{A}, \mathrm{B} ， \mathrm{C})$ を用いて 行った，成形条件をTable I、Table IIに示寸，また、成形機 Cでは引き取り速度や吐出量を变化させてバブル形状を変化 させた．使用樹脂は、LDPE(F023;UBE 製)およびLLDPE(FB123M， FR152B;UBE 製)である. また Farber ら ${ }^{12)}$ のインフレーション 成形実験（LDPE）の成形条件も記寸。バブル表面の温度は放射 温度計で測定した. また成形の様子をビデオカメラに撮影し、 バブル形状の解析を行った，各樹脂の粘弾性測定は、RDSII （Reometrics 社）を使用した。

Table II Processing conditions of molding machine $\mathbf{C}$

\begin{tabular}{cccccc}
\hline \hline C & $\begin{array}{c}Q \\
\mathrm{~kg} / \mathrm{Hr} .\end{array}$ & $\begin{array}{c}\text { DDR } \\
\mathrm{m} / \mathrm{min} .\end{array}$ & $\begin{array}{c}F L H \\
\mathrm{~cm}\end{array}$ & BUR & $\begin{array}{c}H f \\
\mu \mathrm{m}\end{array}$ \\
\hline \hline case1 & 75.0 & 4.0 & 22.0 & 1.493 & 94.4 \\
case2 & 75.0 & 20.0 & 27.0 & 1.510 & 20.2 \\
case3 & 75.0 & 40.0 & 31.0 & 1.497 & 10.0 \\
case4 & 19.7 & 20.0 & 29.0 & 1.952 & 19.0 \\
case5 & 26.0 & 20.0 & 29.0 & 1.956 & 27.0 \\
case6 & 35.7 & 20.0 & 29.0 & 1.956 & 35.8 \\
\hline \hline
\end{tabular}

\section{5. 䊅果と考察}

Fig. 3 は Farber $5{ }^{12)}$ の行ったインフレーション成形実験 (Case3)と Newton 流体でのシミュレーションの比較である. LDPE の活性化エネルギーは $14.0 \mathrm{kcal} / \mathrm{mol}$ で計算した. バブル の半径の計算結果は、樹脂出口からフロストライン付近まで害 験值と一致している.また成形時間に対する温度ブロファイル は、若干計算值が低めであるもののほぼ同等の曲線に乗った诚 少である.フロストラインまでの成形時間の差は 1 秒以内であ り、引き取り速度の差も $0.8 \mathrm{~m} / \mathrm{min}$. と小さく、実駼值を再現し た。またバブル形状から導出した歪み速度は MD、TD ともに寒 験值と比較して絶対値は異なるがほぼ同等の傾向を示した。こ のように樹脂を Newton 流体とおいて計算しても、十分に満足 できる結果を迸き出した。

一方同一成形条件について Leonov モデルを使用して同様な 計算をしたが、式の複雑化により满足できる解を得ることはで きなかった．実際の高分子溶融物は粘弾性体であり、非等二軸 伸長変形を厳密に考慮したモデルで計算するべきである.とこ ろが、インフレーション成形のシミュレーションについては Newton 流体でもそこそこ满足できるな結果が得られている. これは、ゼロ剪断粘度の温度依存性による忘力変化が粘弾性体 の非等二軸伸長変形による各方向の応力変化よりも支配的で あるため、より現実的な粘弾性体の非等二軸伸長変形の効果を 考慮しなくても Newton 流体を仮定した計算で十分に形状をシ ミュレーションできたためであると考えられる。

次に実際に我々が行った成形実惥とシミュレーションとの
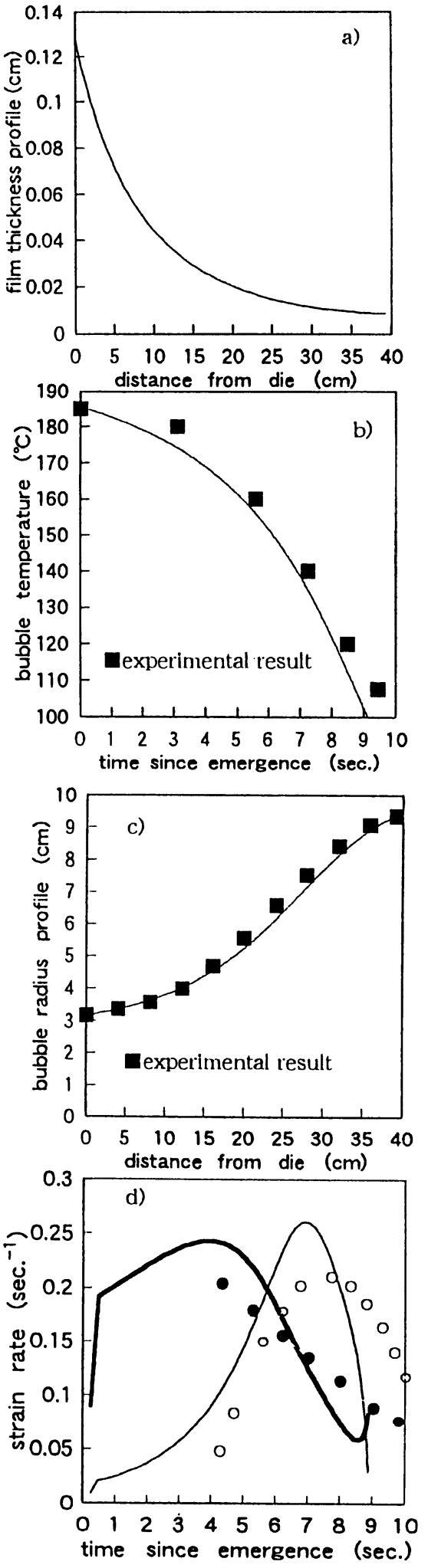

Fig.3 Comparison Farber's results(case3) with calculation results; solid lines are calculated results and symbols are experimental results; a)thickness; b)temperature; c) radius; d) strain rates of MD,TD; and $O$ are MD and TD experimental data; solid line(TD) and bold line(MD) are calculation results;

比較を示す.Fig. 4 は成形機 Aで行った実鈳と計算の結果であ 

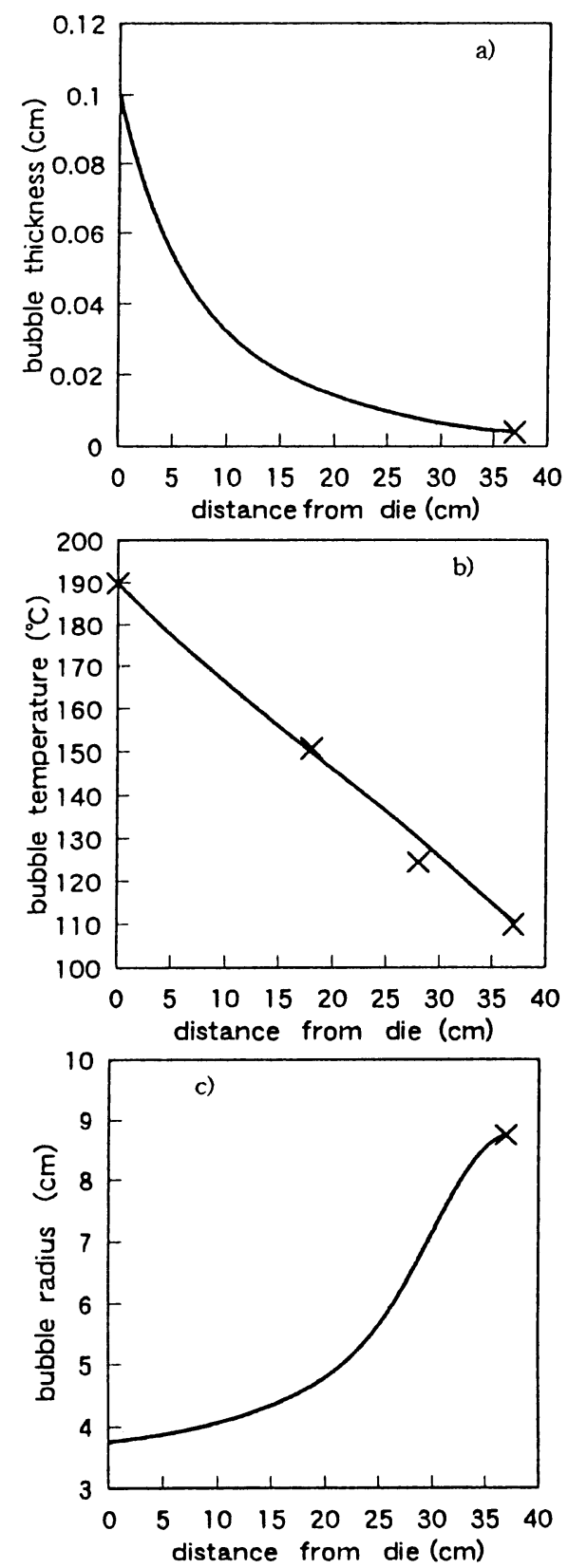

Fig.4 Comparison between experimental results and calculation results thickness; b)temperature; c) radius; symbols are experimental results; solid line are calculated results;

る。使用した樹脂は、LLDPE(FB123B)に 12.5wt\%LDPE(F023)を ドライブレンドしたもので、動的粘弾性測定より求めた活性化 エネルギーは、8. $46 \mathrm{kcal} / \mathrm{mol}$ であった. 歪み速度曲線からダイ スから $20 \mathrm{~cm}$ くらいまでは MD の歪み速度が大きく、ではバブル はほとんど膨らまない. $20 \mathrm{~cm}$ 以降では MD の歪み速度の减少に 対してTDでは增加し $30 \mathrm{~cm}$ 付近で最大になり、バブル半径の変 化は変曲点を持っようになる.ビデオによる実測からバブル形 状の変曲点の位置はダイスから $30 \mathrm{~cm}$ の高さであり、計算結果 でも同等の傾向を示した。またMDの歪み速度はフロストライ ンに近づくにつれ增加する傾向がみられる.これはフロストラ イン近傍でTDの歪み速度の诚少に対して、厚み方向の歪み速 度の减少が小さいために結果としてMDの歪み速度は大きくな
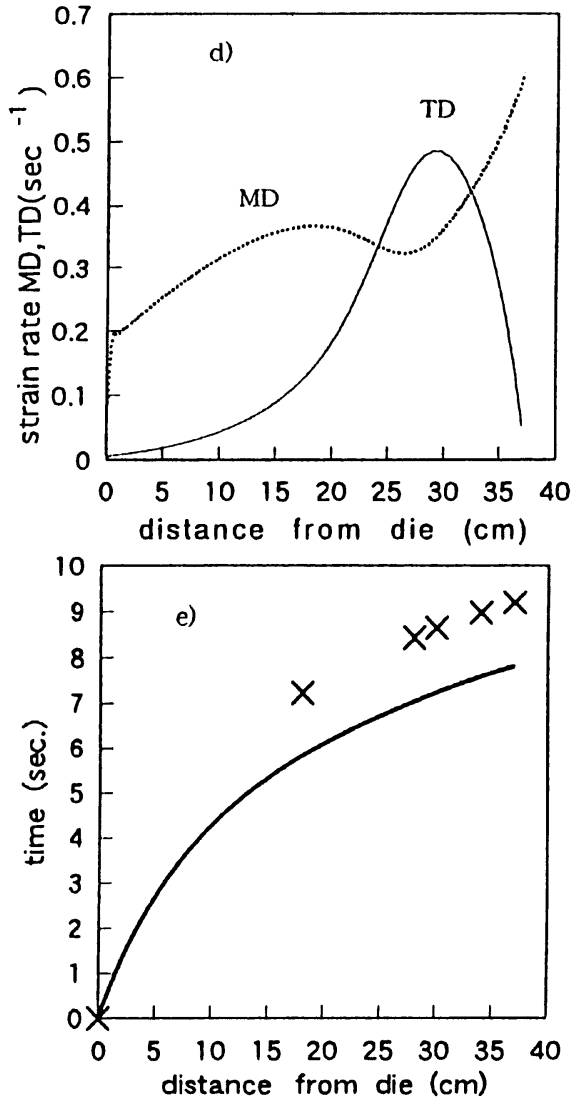

Fig.4 Continued. d)strain rates; solid line(TD) and dot line(MD) are calculation results; e)processing time;

Table III Calculated results of difference air ring heights

\begin{tabular}{cccc}
\multicolumn{4}{c}{ on film blowing processing } \\
\hline air ring height (cm) & 0.0 & 5.0 & 10.0 \\
blow up ratio & 1.31 & 1.22 & 1.19 \\
final thickness $(\mu \mathrm{m})$ & 150.0 & 42.8 & 10.7 \\
frostline height $(\mathrm{cm})$ & 35.0 & 40.0 & 45.5 \\
processing time $(\mathrm{sec}$ ) & 13.2 & 8.9 & 6.4 \\
drawing rate $(\mathrm{m} / \mathrm{min}$ ) & 6.1 & 23.0 & 94.4 \\
\hline
\end{tabular}

ると考えられる.また、温度プロファイルは実検データを良く 再現している.

さらにダイス径の大きい成形機 Bでの実験結果と計算結果 の比較をFig. 5 に示す. 使用した樹脂は LDPE(F023)で、活性 化エネルギーは、動的粘弾性測定から $13.44 \mathrm{kcal} / \mathrm{mol}$ であった. またエアリング吹き出しロは成形ダイスから $5 \mathrm{~cm}$ の高さにあ ったため、高さ $5 \mathrm{~cm}$ から冷却風の影警を考慮して計算を行っ た. バブル温度は、冷却風が直接噴射される前には約 $3^{\circ} \mathrm{C}$ 温 度低下しか起こしていないが、鲴射後には急激に椧却していく 様子がわかる.

この手法を応用することにより、バブル形状の高さ依存性を 調べることができる.エアリング高さの効果は、今日一般的で ある多層にわたった複雑なエアリング形状をシミュレーショ 

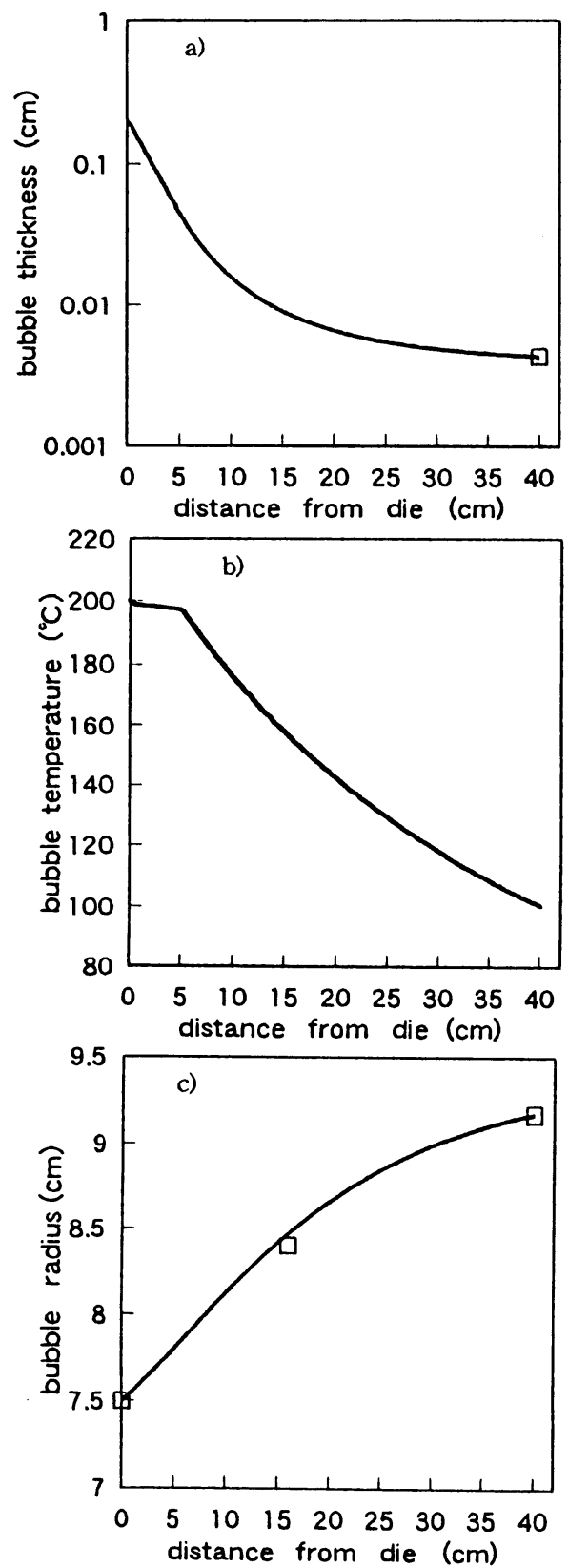

Fig.5 Comparison between experimental results and calculation results;symbols are experimental results ; solid lines are calculated results;a) thickness b) temperature; c) radius

ンする際、考慮にいれるべき重要なバラメーターである，Fig. 6 はFig. 5 の結果をもとに、エアリング高さが $0 \mathrm{~cm} 、 5 \mathrm{~cm}$ お び $10 \mathrm{~cm}$ でのバブルの变化を示している. 同一張力で MD 引っっ ばった際、エアリング高さが $0 \mathrm{~cm}$ では楜脂が吐出された直後に 冷却が開始されるため樹脂の粘度が上昇し、 $5 \mathrm{~cm}$ に比べて厚み の堿少は少なくなる.また、冷却開始地点が低くなるためにフ ロストラインは冷却風高さが堿っただけ減少する.しかし Table IIIから分かるように、成形時閒は 4 秒以上長くなった. これはフロストライン位置の低下により、同一張力を得るため に必要とされる引き取り速度が小さくなり $(V f=6.1 \mathrm{~m} / \mathrm{min}$. $)$ そ の結果成形時間が增寸と考えられる. またバブル半径も、引き
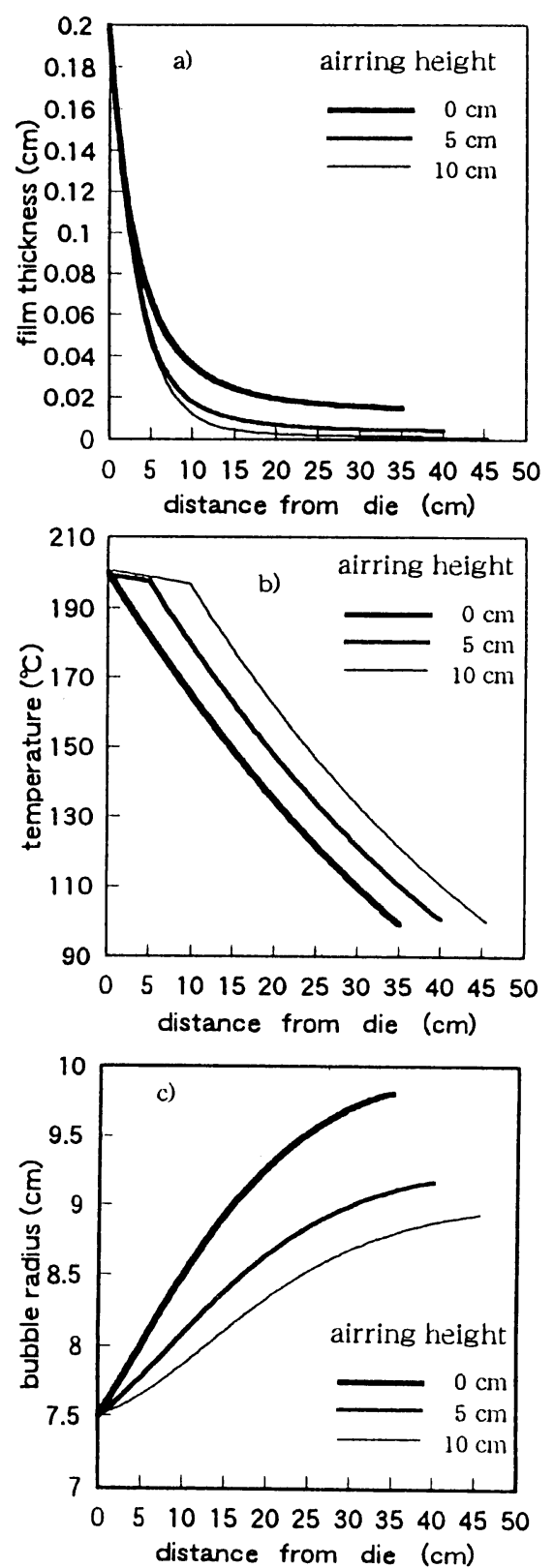

Fig.6 The dependence of calculated bubble profile for the air ring height of film blowing processing ;a) thickness; b) temperature; c) radius

取り速度の低下により成形時閒が長くなるため、同じ内圧のも とでも膨らむ傾向にある.エアリング高さを $10 \mathrm{~cm}$ に設定した 場合では、樹脂が吐出されてから約 $10 \mathrm{~cm}$ の位置までに低下す る温度は 5 度くらいと小さく、同一張力を与えたとき、粘度が 低いために大きく変形していき、厚みの城少が大きくなる，ま たフロストライン位置が高くなることによって、必要な引き取 り速度は速くなり $(V f=94.4 \mathrm{~m} / \mathrm{min}$. ）、成形時間は $6.4 \mathrm{sec}$ 上短 くなる.これによって同一内圧でもバブルはあまり膨らまず、 ブロー比は減少する.

以上の結果は、エアリング形状によるバブルの形状の変化を 見積もるための基礎的データとなる．上記条件での MDおよび 

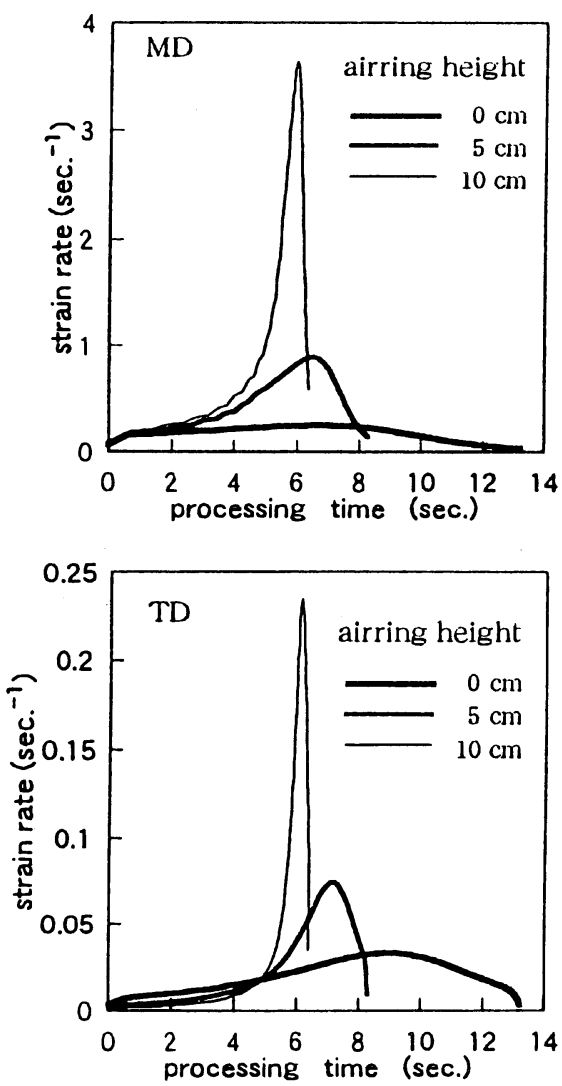

Fig.7 The dependence of calculated strain rate protiles for the air ring height of film blowing processing;

Table IV Comparison between experimental results and calculated results for drawing rate or final thickness; $Q=75.0 \mathrm{~kg} / \mathrm{Hr}$

\begin{tabular}{ccccc}
\hline & \multicolumn{2}{c}{$\begin{array}{c}\text { drawing rate } \\
\text { (m/min.) } \\
\text { experimental } \\
\text { value }\end{array}$} & calculation & \multicolumn{2}{c}{$\begin{array}{c}\text { final film thickness } \\
(\mu \mathrm{m}) \\
\text { experimental } \\
\text { value }\end{array}$} & calculation \\
\hline case 1 & 4.0 & 5.03 & 94.4 & 94.7 \\
case 2 & 20.0 & 22.74 & 20.2 & 20.8 \\
case 3 & 40.0 & 45.54 & 10.0 & 10.5 \\
\hline \hline
\end{tabular}

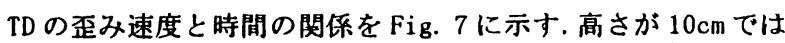
シャープで最大值の大きな歪み速度分布であるのに対し、0cm ではブロードな最大值の小さいピーク分布になっている.これ らは引き取り速度の大きさに対応しているものと思われる。

Fig. 7 の歪み速度の時間に対する変化から求めた歪み量を Table IVに示寸．MDの歪み量は、0cm では $227 \% 、 5 \mathrm{~cm}$ で $360 \%$ 、 $10 \mathrm{~cm}$ で $500 \%$ と薄膜化するにつれて大きくなる，一方、TDで は $0 \mathrm{~cm}$ で $27 \% 、 5 \mathrm{~cm}$ で $20 \% 、 10 \mathrm{~cm} て ゙ 17 \%$ と冷却風高さが高く なるに従い歪み量は堿少していく.これは、椧却風高さによっ て引き取り速度が大きくなることにより、MD の歪み量が增大 し、TD の歪み量が堿少していくことを意味する．よってフィ ルムの異方性は椧却風高さが大きくなるにつれて、大きくなる。
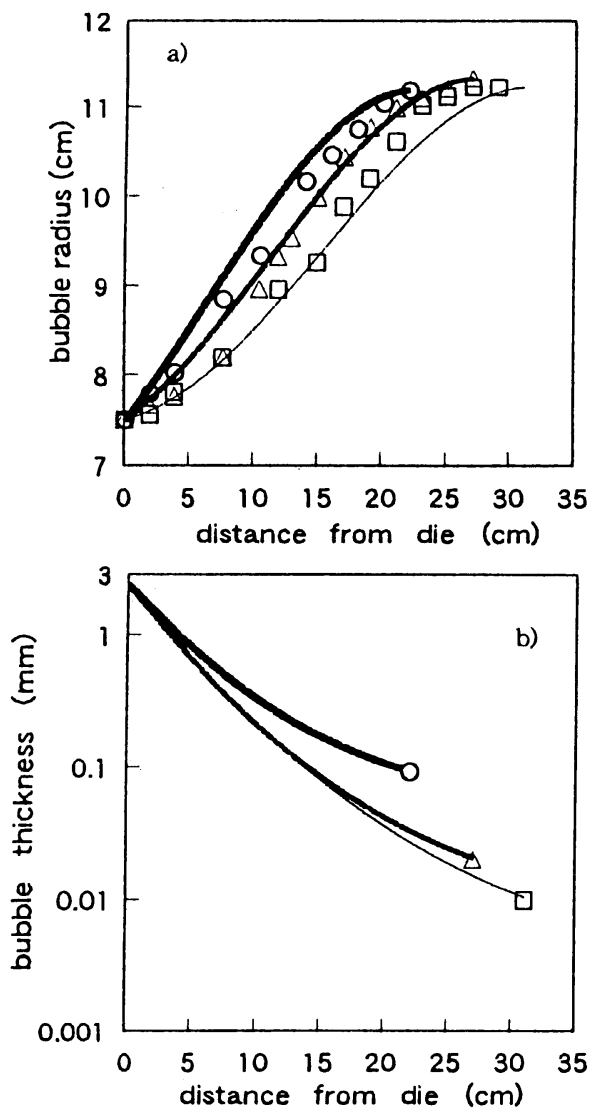

Fig.8 The dependence of bubble protiles for drawing rate; $\bigcirc 4.0 \mathrm{~m} / \mathrm{min}$; $\triangle 20.0 \mathrm{~m} / \mathrm{min}$.; $\square 40.0 \mathrm{~m} / \mathrm{min}$;; a)radius ; b) thickness ;solid lines are calculated;

Table V Comparison of experimental results and calculated results for mass tlow or final thickness; $\mathrm{Vf}=20.0 \mathrm{~m} / \mathrm{min}$.

\begin{tabular}{|c|c|c|c|}
\hline & \multirow[t]{2}{*}{$\begin{array}{c}\text { mass flow } \\
(\mathrm{kg} / \mathrm{Hr} .)\end{array}$} & \multicolumn{2}{|c|}{$\begin{array}{l}\text { final film thickness } \\
\qquad(\mu \mathrm{m})\end{array}$} \\
\hline & & experimental value & calculation \\
\hline case 4 & 19.7 & 19.0 & 22.7 \\
\hline case 5 & 26.0 & 27.0 & 27.5 \\
\hline case 6 & 35.7 & 35.8 & 35.9 \\
\hline
\end{tabular}

このように計算から求めた歪み量自体は、樹脂をニュートン流 体と仮定して求めた結果であるため定量性はないが、フィルム の配向性を評価する指標の一つとすることができる.以上のよ うにシミュレーションすることにより定性的に、冷却風高さが フィルムの成形条件のみならず物性にも多大な影響を及ぼし ていることが分かる.

実際の成形中に最も頻繁に操作するパラメーターは、引き取 り速度および吐出量である.これらの変化によりバブル形状が どの様に変化するかについて、これまでは経験的に理解してい たことではあるが、理論的な解析例はあまりない、今回成形機 Cを用いてこの 2 種類のバラメーターについて条件を種々変 化させて実験を行い、計算との比較を行った. 計算では使用し 

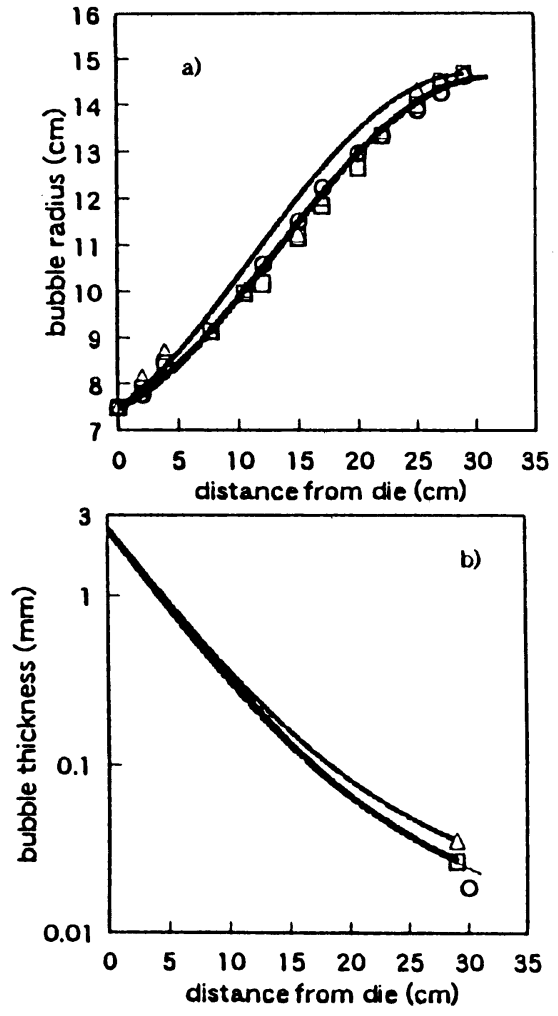

Fig.9 The dependence of bubble profiles for mass flow; $\bigcirc 19.7 \mathrm{Kg} / \mathrm{Hr} ; \square 26.0 \mathrm{Kg} / \mathrm{Hr}$; $\triangle 35.7 \mathrm{Kg} / \mathrm{Hr}$.; a)radius ; b) thickness ; solid lines are calculated;

た榯脂の動的粘弾性測定から求めた活性化エネルギー $6.00 \mathrm{kcal} / \mathrm{mol}$ を使用した.

Fig. 8には吐出量およびブロー比を一定とした条件下で、引 き取り速度を 4.0、20.0、40.0 $\mathrm{m} / \mathrm{min}$ と変えたときのバブル半 径の変化および厚みの诚少を示している. Table IVには引き取 り速度とフィルムの最終厚みの計算值と実験値との比较を示 している. 図から明らかなように、引き取り速度を上げること によりフロストライン高さが上昇する.またバブル半径の変化 は引き取り速度が变化してもほぼ実験結果を再現している. 一 方、計算で求めた引き取り速度は実験值よりも若干大きく、そ の差は引き取り速度が大きくなるにつれて広がった，また、フ イルム厚みは引き取り速度を 2 倍にすると半分になることが 経臨的にわかっているが、計算結果も実験結果を再現するもの であった。

Fig. 9 では引き取り速度およびブロー比一定の下、吐出量を 変化させたときのバブル半径の変化および厚みの減少を示し ている. また Table Vには吐出量を変化させたときのフィルム の最終厚みの計算值と実験值との比較を示している.吐出量の 增加によるフロストライン高さの上昇は引き取り速度の增加 に比へててとんどない.厚みは吐出量を增加させることにより 多少增加寸るが、引き取り速度による变化ほど顕著ではない。 計算結果は実験値と比较して吐出量が低い方では少し誤差が 生じるが、おおよその傾向は捕らえることが出来ている。

\section{6. 䊅敦}

微分方程式の解法に Band Matrix 法を用い、Newton-Raphson 法と組み合わせることによって成形条件を迸き出すことの出 来る、インフレーション成形自動シミュレーションプログラム を作成した. 実際の成形結果との比㜞をした結果、樹脂の粘弾 性的性梊を Newton 流体で仮定しても、比较的精度良くバブル の形状を導き出せることが分かった. 本シミュレーションソフ 卜は定性的な成形条件分析には十分に適用可能であると考え られる.また、各位圈における応力やひずみ速度なども同時に 解析でき、今後のフィルムの配向解析などに応用できると考え られる.

特に椧却風の高さは、フィルムの成形条件のみならず物性に も多大な影響を及ぼしていることが明確となった.近年椧却風 吹き出し口が複数からなる成形機が主流を占めており、これら に対匛していくためには、この種の解析はますます重要になっ てくるであろう.また引き取り速度や吐出量などの、通常よく 変化させる成形条件の成形フィルム状態依存性も、本ソフトで 十分にシミュレーションが可能であることが分かった.

\section{Appendix}

論文中の各記号の定義

$R_{0}$;成形ダイス半径

$H_{0}$ ダイスギャップ

$Z_{\text {sir }} ;$ エアリング高さ

$R_{f} ;$ フロストラインでのバブル半径

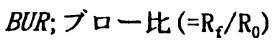

$H_{f} ;$ 最終的なフィルム厚み

$T_{0} ;$ 成形樹脂温度

$Q$; 吐出量

$T_{\text {room; }}$ 成形案囲気温度

$F L H ;$ フロストライン高さ

$A_{E} ;$ 活性化エネルギー

$T_{\text {iir }}$ 冷却風温度

$T_{f} ;$ 変形停止温度

》。:ゼロ前断粘度

$\varepsilon$ „; 輻射率

$\triangle P$; 内压

$F_{z} ;$ 引き取り張力

$U$; 熟伝達倸数

$\varepsilon ;$ 収束条件

$\alpha, \beta, \gamma ;$ 变数

\section{参考文献}

1) Pearson J.R.A.Petrie C.J.S.,J Fluid Mech ,42,609(1970)

2) Pearson J.R.A.,Petrie C.J.S.,Plastics Polym ,38,85(1970)

3) Han C.D.,Park J.Y.,J Appl Polym Sci , 19,3277(1975)

4) Kanai T.,White J.L.,Polym Eng Sci ,24,1185(1984)

5) Minoshima W.,White J.L.,J Non-Newtonian Fluid

Mech ,19,275,(1986)

6)Sweeney P.A.,Campbell G.A.F.A.Feeney,Int Polym

Process , 7,229(1992)

7) Cain J.J.,Denn M.M.,Polym Eng Sci ,28,1527(1988)

8) Luo X.L.,Tanner R.I.,Polym Eng Sci ,25,620(1985)

9) Alaie S.M.,Papanastasiou T.C.,Int Polym Process ,1,51(1993)

10)LiuC.C.,Bogue D.C.,SpruiellJ.E.,Int Polym Process ,3,226(1995)

11) Newman J.,I \&E C Fundamentals, 7,514(1968)

12) Farber R.,Dealy J.M.,Polym Eng Sci ,14,435(1974) 